\title{
FUNCTIONAL GROUPS OF BENTHIC MACROINVERTEBRATES IN RELATION TO PHYSICOCHEMICAL FACTORS IN KEQIN LAKE, ZHALONG NATIONAL NATURE RESERVE, NORTHEASTERN CHINA
}

\author{
LI, X. Y. ${ }^{1}-$ LIU, M. H. $.^{*}-$ SUN, X. ${ }^{1}-$ LI, S. ${ }^{1}-$ ZHAO, Y. X. ${ }^{1}-$ LIU, D. ${ }^{1}-$ CHAI, F. Y. ${ }^{2}-$ YU, H. X. ${ }^{1 *}$ \\ ${ }^{I}$ College of Wildlife and Protected Area, Northeast Forestry University, Harbin 150040, China
}

${ }^{2}$ School of Management, Heilongjiang University of Science and Technology, Harbin 150027, China

*Corresponding authors

e-mail: manhong@nefu.edu.cn (M. H. Liu); china.yhx@163.com (H.X.Yu)

(Received 31 $1^{\text {st }}$ Jul 2020; accepted $19^{\text {th }}$ Nov 2020)

\begin{abstract}
Using functional traits to represent functional components and functional diversity help us better understand ecosystem and community functions. Species' functional traits are sensitive to environmental change, and can potentially indicate these changes through community and population succession. In order to grasp the spatial and temporal distribution pattern of functional characteristics and the influence of physicochemical factors on the functional diversity of benthic macroinvertebrates in Keqin Lake (in Zhalong National Nature Reserve of China), we investigated the benthic macroinvertebrates and physicochemical indexes in May, July and October 2019. Referring to the relevant literature, we selected the functional feeding groups and the locomotion groups for analysis. According to the research results, 21 taxa were identified; Palaemonidae, Viviparidae and Chironomidae accounted for the largest proportion, their relative abundances were $51.05 \%, 15.26 \%$, and $13.68 \%$ respectively. OM (Omnivores) was the dominant group in the functional feeding groups, and CM (Climbers) was the dominant group among the locomotion groups. The One-way analysis of variance (ANOVA) and Honestly significant difference (HSD) tests showed significant differences in the following physicochemical factors: WT, SD, NTU, $\mathrm{NH}_{4}{ }^{+}-\mathrm{N}, \mathrm{Cl}^{-}$and $\mathrm{COD}_{\mathrm{Mn}}$. Redundancy analysis (RDA) results displayed that $\mathrm{COD}_{\mathrm{Mn}}, \mathrm{Cl}^{-}$and NTU were significant indexes that affected the functional feeding groups and the locomotion groups.
\end{abstract}

Keywords: functional feeding groups, locomotion groups, lake, benthic macroinvertebrates, physicochemical factors

\section{Introduction}

Ecosystem function is a broad concept, including ecosystem processes (such as nutrient cycle), ecosystem services (such as providing fish, habitat, filtration, etc.), resilience and resistance to interference (Daily, 1997; Postel and Carpenter, 1997). Climate change leads to seasonal changes in the environmental characteristics of the whole lake area, including hydrological characteristics, physical and chemical factors, and lakeshore vegetation, and ultimately altering the community structure of benthic macroinvertebrates by affecting the growth, reproduction and species succession. The research of functional traits provides a new way to further understand this process (Zhang et al., 2016; Liu et al., 2019b; Alcocer et al., 2016).

At present a popular approach has been proposed in benthic macroinvertebrates functional groups to assess ecosystem health. These groups of species have more or less precisely defined demands via several different combinations of morphological and behavioral features. Compared with taxonomic methods, functional groups are more 
accurate in assessing response to changes concerning the environment (Bremner et al., 2006; Gamito et al., 2009). As an example, variations have been observed in the functional feeding groups and the locomotion groups for benthic macroinvertebrates in a stressed environment subjected either to anthropogenic influence or to natural environmental stress. Thus, functional groups are useful as an assessment tool in ecosystem health (Usseglio-Polatera et al., 2000).

Benthic macroinvertebrates are typical biological groups in aquatic ecosystems, which have been regarded as model groups by some domestic scholars. The classification of species into functional groups according to the similar biological and ecological characteristics, and several domestic researchers have done researches on benthic macroinvertebrates functional groups in rivers and lakes ecosystems. Researchers believe that the specific characteristics of functional groups are more closely related to the environment. These characteristics can directly reflect the community structure and habitat adaptability of benthic macroinvertebrates, as well as the impact caused by human activities to aquatic ecosystem (Li et al., 2019; Liu et al., 2019a; Zhu et al., 2020).

Cummins (1973) was the first biologist to make clear use of the functional classification of aquatic organisms, and divide the functional groups of food intake by the priority feeding mode of macroinvertebrates. The functional feeding groups functional group are divided into six groups: Filter-feeders (FC), Omnivores (OM), Predators (PR), Scrapers (SC), Shredders (SH) and Collectors (GC). Morse et al. (1994), Usseglio-Polatera et al. (1994) and Poff et al. (2006) also proposed the classification of macroinvertebrates habits or modes of existence. He divided locomotion groups into eight groups: Burrowers (BU), Climbers (CM), Clingers (CN), Divers (DI), Sprawlers (SP), Skaters (SK), Planktonic (PL) and Swimmers (SW). In our research only mentioned four groups in functional feeding groups and five groups in locomotion groups (Table 1).

Zhalong National Nature Reserve $\left(123^{\circ} 47^{\prime}-124^{\circ} 37^{\prime} \mathrm{E}, 46^{\circ} 52^{\prime}-47^{\circ} 32^{\prime} \mathrm{N}\right.$, total area $2100 \mathrm{~km}^{2}$ ), located in western Heilongjiang Province, northeast China, was established in 1985. The reserve is mostly dominated by reed marsh, other common plants including Cattail (Typha orientalis Presl). The rapid development of industrialization and urbanization in the surrounding area of Zhalong National Nature Reserve (ZNNR) over the past decades to finally give the negative impacts on the water resources. The discharge of industrial wastewater, agricultural wastewater, and domestic sewage from the upper reaches (Wuyur River) of Keqin lake made water quality decline. However, in the ecosystem health assessment of Keqin Lake (the largest lake in ZNNR) vacancy benthic macroinvertebrates functional groups.

The purpose of this study was to assess the spatial and temporal variation of functional groups of benthic macroinvertebrates in the Keqin Lake, northeastern China, and how it is influenced by the seasonally varying physicochemical properties of the lake. Nine sites across the lake were sampled for benthic macroinvertebrates and physicochemical variables in spring, summer and autumn. benthic macroinvertebrates were categorized in functional feeding groups and locomotion groups and their relative abundance was evaluated in relation to major physicochemical factors. This is the first study that explores relationships between benthic macroinvertebrate functional groups and physicochemical factors in the Keqin Lake, and its results are expected to facilitate the development of ecological restoration strategies towards the sustainable management of the lake's biota. 


$$
-281 \text { - }
$$

Table 1. Division of functional groups of benthic macroinvertebrates

\begin{tabular}{|c|c|c|c|}
\hline $\begin{array}{c}\text { Functional } \\
\text { group }\end{array}$ & Traits & Abbreviation & Modalities \\
\hline \multirow{4}{*}{$\begin{array}{c}\text { Functional } \\
\text { feeding groups }\end{array}$} & Filter-feeders & $\mathrm{FC}$ & $\begin{array}{l}\text { Decomposing fine particulate organic matter (FPOM). } \\
\text { Detritivores-filters or suspension feeders. Detritivores- } \\
\text { gatherers or deposit (sediment) feeders (includes feeders } \\
\text { on loose surface films). }\end{array}$ \\
\hline & Omnivores & $\mathrm{OM}$ & $\begin{array}{l}\text { Omnivores rely on the skin or gills to directly absorb the } \\
\text { dissolved organics in water, and it can also eat the decayed } \\
\text { leaves of plants, small bivalves and crustaceans. }\end{array}$ \\
\hline & Predators & PR & $\begin{array}{c}\text { Living animal tissue. Engulfers-carnivores, ingest whole } \\
\text { animals or parts. Piercers- carnivores, pierce tissues and } \\
\text { cells to suck fluids. }\end{array}$ \\
\hline & Scrapers & $\mathrm{SC}$ & $\begin{array}{c}\text { Periphyton-attached algae and associated material. } \\
\text { Herbivores- grazing Scrapers of mineral and organic } \\
\text { surfaces. }\end{array}$ \\
\hline \multirow{5}{*}{$\begin{array}{l}\text { Locomotion } \\
\text { groups }\end{array}$} & Burrowers & $\mathrm{BU}$ & $\begin{array}{l}\text { Inhabiting the fine sediments of streams (pools) and lakes. } \\
\text { Some construct discrete burrows that may have sand grain } \\
\text { tubes extending above the surface of the substrate or the } \\
\text { individuals may ingest their way through the sediments. } \\
\text { Some burrow (tunnel) into plant stems, leaves, or roots } \\
\text { (miners). }\end{array}$ \\
\hline & Climbers & $\mathrm{CM}$ & $\begin{array}{l}\text { Adapted for living on vascular hydrophytes or detrital } \\
\text { debris (such as overhanging branches, roots and vegetation } \\
\text { along streams, and submerged brush in lakes). With } \\
\text { modifications for moving vertically on stem-type surfaces. }\end{array}$ \\
\hline & Clingers & $\mathrm{CN}$ & $\begin{array}{l}\text { Representatives have behavioral (such as fixed retreat } \\
\text { construction) and morphological (such as long, curved } \\
\text { tarsal claws, dorsoventral lattening, and ventral gills } \\
\text { arranged as a sucker) adaptations for attachment to } \\
\text { surfaces in stream riffles and wave-swept rocky littoral } \\
\text { zones of lakes. }\end{array}$ \\
\hline & Divers & DI & $\begin{array}{l}\text { Adapted for swimming by "rowing" with the hind legs in } \\
\text { lentic habitats and lotic pools. Representatives come to the } \\
\text { surface to obtain oxygen, dive and swim when feeding or } \\
\text { alarmed; may cling to, or crawl on, submerged objects } \\
\text { such as vascular plants. }\end{array}$ \\
\hline & Sprawlers & SP & $\begin{array}{l}\text { Inhabiting the surface of floating leaves of vascular } \\
\text { hydrophytes or fine sediments, usually with modification } \\
\text { for staying on top of the substrate and maintaining the } \\
\text { respiratory surfaces free of silt. }\end{array}$ \\
\hline
\end{tabular}

\section{Methods}

\section{Study area}

ZNNR is one of the most important wetland reserves in the world. Keqin lake is the largest inland lake in this region which is divided into two lakes, North Lake and South Lake, from $124^{\circ} 16^{\prime} 51^{\prime \prime} \mathrm{E}$ to $124^{\circ} 19^{\prime} 9^{\prime \prime} \mathrm{E}$ and from $47^{\circ} 17^{\prime} 7^{\prime} \mathrm{N}$ to $47^{\circ} 20^{\prime} 13$ 'N $\mathrm{N}$, covering a total area of $27 \mathrm{~km}^{2}, 3 \mathrm{~m}$ mean depth, and storage capacity is $34,500,000 \mathrm{~m}^{3}$. Keqin lake is adjacent to the eastern suburb of Qiqihar City (30 km away from Qiqihar city), located on the west bank of Wuyur River, the surrounding area is low-lying, with a large area of marsh wetland. The region where located the lake is influenced by the continental monsoon in the cold temperate with an annual average temperature of 
$1{ }^{\circ} \mathrm{C} \sim 4.2{ }^{\circ} \mathrm{C}$, and a range of $-35.0^{\circ} \mathrm{C} \sim 36.6^{\circ} \mathrm{C}$. The lake area is dry and windy in the spring, hot and rainy in the summer, cool in the autumn, and long and cold in the winter. Water supply depends on the lake surface precipitation and the land runoff, and the main river entering the lake is Jiudaogou (a tributary of Wuyuer River). Meadow covers the lake beaches where mainly growing aquatic vascular plants are Phragmites australis and Typha orientalis. Keqin Lake is also a stocking lake which stocked fishes of the Cyprinidae (Mylopharyngodon piceus, Ctenopharyngodon idellus, Hypophthalmichthys molitrix, Aristichthys nobilis) and crab of the Eriocheir genus.

\section{Field sampling and laboratory analysis}

According to the temperature conditions of the area where Keqin lake is located, benthic macroinvertebrates were collected in spring (May), summer (July) and autumn (October) of 2019 in Keqin lake, and 9 sampling sites were set according to the water conditions and surrounding environment characteristics of Keqin Lake (Fig. 1; Table 2). Sites S1, S2, S3 were near the bank, with luxuriant vegetation; Site S2 bottom was covered by sandy mud; Site S5 was inlet; Sites S4, S6, S7, S8, S9 were in the middle of the lake with white mud bottom.



Figure 1. Location of the nine sites, sampled in spring, summer and autumn 2019, in the Keqin Lake, Northeastern China

D-frame aquatic net $(30 \times 30 \mathrm{~cm}$ frame, $500 \mu \mathrm{m}$ mesh $)$ was used to collect benthic macroinvertebrates; For the deep mud bottom, the Peterson dredger is used with a sampling area of $1 / 16 \mathrm{~m}^{2}$; Sampling area of the D-frame and the dredger were the same $\left(1 \mathrm{~m}^{2}\right)$. In three sampling periods, three duplicate samples were collected at each sampling 
point and screened by $500 \mu \mathrm{m}$ mesh sieve. Macroinvertebrate populations are separated carefully by hand from matrix (sand and mud). All samples were stored in $95 \%$ ethanol for further analysis in the laboratory. The identification of benthic macroinvertebrates was carried out under anatomical microscope (Motic SMZ-168) and microscope (Motic BA400). Species identification used professional classification books (Thorp and Covich, 1991; Morse et al., 1994; Merritt et al., 1996; Dudgeon, 1999; Duan et al., 2010), and most samples were identified to species, others to families and genera.

Table 2. Coordinates of sampling sites in Keqin Lake

\begin{tabular}{c|c|c}
\hline Sampling sites & Latitude & Longitude \\
\hline S1 & N47.2834641272510 & E124.283886360844 \\
S2 & N47.2855369101671 & E124.307603087027 \\
S3 & N47.3026818647690 & E124.285532823154 \\
S4 & N47.3338851781492 & E124.306637783286 \\
S5 & N47.3426645628785 & E124.322344250396 \\
S6 & N47.2953089333742 & E124.292401182075 \\
S7 & N47.3128415296640 & E124.293206284997 \\
S8 & N47.3086889661881 & E124.306911649462 \\
S9 & N47.2968542838218 & E124.307352675974 \\
\hline
\end{tabular}

The physicochemical factors: WT (water temperature), EC (conductivity), DO (dissolved oxygen), $\mathrm{NH}_{4}{ }^{+}-\mathrm{N}$ (ammonium nitrogen), $\mathrm{NO}^{3-}-\mathrm{N}$ (nitrate nitrogen), $\mathrm{Cl}^{-}$ (chlorion), NTU (turbidity) and $\mathrm{pH}$ were measured by a portable multi-probe (YSI 6600) in the wild; Secchi disk was used to measure SD (Water transparency); The TN (total nitrogen), TP (total phosphorus) and $\mathrm{COD}_{\mathrm{Mn}}$ (chemical oxygen demand) were measured in accordance with "water and wastewater monitoring and analysis method" for China (Wei et al., 2002).

\section{Data analysis}

The significance of the differences in abiotic data between the three periods was tested using one-way ANOVA and a posteriori Tukey's HSD tests. Data were analyzed using the SPSS 19.0 software.

Associations between the relative abundance of benthic macroinvertebrates functional groups and physicochemical parameters were measured by a redundancy analysis (RDA), by using the CANOCO 4.5 software. The RDA analysis was selected since the Detrended Correspondence Analysis (DCA) identified that biological data were linearly responding to environmental gradients (the largest lengths of gradient value of 4 axis was $2.691(<3)$ ). All continuous physicochemical factors and benthic macroinvertebrates abundance were $\log _{10}(1+\mathrm{x})$ transformed before DCA analysis.

\section{Results}

\section{Variation of physicochemical factors in different seasons}

The One-way ANOVA results showed in Table 3, we can find that most of these variables have significant differences between different sampling times, and they were 
at a low significant level $(p<0.05)$. HSD tests revealed that significant differences were found among three sampling periods.

WT was significantly higher in summer than in spring and autumn $(p<0.05)$, while SD was remarkable lower in spring than in summer and autumn $(p<0.05)$, NTU and $\mathrm{NH}_{4}{ }^{+}-\mathrm{N}$ were notable higher in spring than in summer and autumn $(p<0.05, p<0.05)$, whereas $\mathrm{Cl}^{-}$and $\mathrm{COD}_{\mathrm{Mn}}$ were significantly higher in autumn than in summer and spring $(p<0.05, p<0.05)$.

Table 3. Variation of physicochemical factors in different seasons (mean $\pm S E$ ). SD: water transparency; WT: water temperature; EC: conductivity; $\mathrm{Cl}$ : chlorion; $\mathrm{NH}_{4}{ }^{+}-\mathrm{N}$ : ammonium nitrogen, NO3-N: nitrate nitrogen; NTU: turbidity; DO: dissolved oxygen; TN: total nitrogen; TP: total phosphorus; $C O D_{M n}$ : chemical oxygen demand. P-value comes from One-way ANOVA and a, b, c measured by post-hoc test using Tukey HSD ANOVA, which mean differences between three seasons

\begin{tabular}{c|c|c|c|c}
\hline & Spring & Summer & Autumn & $\boldsymbol{P}$-value \\
\hline $\mathrm{SD}(\mathrm{cm})$ & $9.75 \pm 0.12^{\mathrm{a}}$ & $24.89 \pm 2.90^{\mathrm{b}}$ & $26.11 \pm 2.61^{\mathrm{b}}$ & 0.000 \\
$\mathrm{WT}\left({ }^{\circ} \mathrm{C}\right)$ & $15.43 \pm 0.09^{\mathrm{a}}$ & $21.39 \pm 0.11^{\mathrm{b}}$ & $6.61 \pm 0.29^{\mathrm{c}}$ & 0.000 \\
$\mathrm{EC}(\mathrm{ms} / \mathrm{cm})$ & $0.39 \pm 0.04^{\mathrm{a}}$ & $0.32 \pm 0.04^{\mathrm{a}}$ & $0.35 \pm 0.03^{\mathrm{a}}$ & 0.400 \\
$\mathrm{pH}$ & $9.50 \pm 0.06^{\mathrm{b}}$ & $9.50 \pm 0.04^{\mathrm{b}}$ & $9.72 \pm 0.06^{\mathrm{a}}$ & 0.012 \\
$\mathrm{Cl}^{-}(\mathrm{mg} / \mathrm{L})$ & $23.11 \pm 0.93^{\mathrm{b}}$ & $21.09 \pm 1.41^{\mathrm{b}}$ & $53.06 \pm 3.86^{\mathrm{a}}$ & 0.000 \\
$\mathrm{NH}_{4^{+}}-\mathrm{N}(\mathrm{mg} / \mathrm{L})$ & $48.49 \pm 4.73^{\mathrm{a}}$ & $21.24 \pm 1.29^{\mathrm{b}}$ & $12.48 \pm 1.66^{\mathrm{b}}$ & 0.000 \\
$\mathrm{NO}_{3}{ }^{-}-\mathrm{N}(\mathrm{mg} / \mathrm{L})$ & $15.58 \pm 0.71^{\mathrm{a}}$ & $35.66 \pm 2.41^{\mathrm{b}}$ & $24.28 \pm 0.85^{\mathrm{c}}$ & 0.000 \\
$\mathrm{NTU}$ & $51.87 \pm 1.04^{\mathrm{a}}$ & $26.30 \pm 4.21^{\mathrm{b}}$ & $32.62 \pm 4.58^{\mathrm{b}}$ & 0.000 \\
$\mathrm{DO}(\mathrm{mg} / \mathrm{L})$ & $7.09 \pm 0.41^{\mathrm{b}}$ & $9.29 \pm 0.20^{\mathrm{a}}$ & $8.36 \pm 0.23^{\mathrm{a}}$ & 0.000 \\
$\mathrm{TN}(\mathrm{mg} / \mathrm{L})$ & $2.17 \pm 0.28^{\mathrm{a}}$ & $1.41 \pm 0.22^{\mathrm{ab}}$ & $2.33 \pm 0.27^{\mathrm{ac}}$ & 0.042 \\
$\mathrm{TP}(\mathrm{mg} / \mathrm{L})$ & $0.40 \pm 0.02^{\mathrm{a}}$ & $0.58 \pm 0.07^{\mathrm{a}}$ & $0.58 \pm 0.15^{\mathrm{a}}$ & 0.322 \\
$\mathrm{COD} D_{\mathrm{mn}}(\mathrm{mg} / \mathrm{L})$ & $21.56 \pm 0.88^{\mathrm{a}}$ & $22.36 \pm 0.39^{\mathrm{a}}$ & $40.09 \pm 2.79^{\mathrm{b}}$ & 0.000 \\
\hline
\end{tabular}

\section{The characteristics of benthic macroinvertebrates communities structures}

In the investigation, 21 taxa were identified in a total of 190 individuals (Table 4). Relative abundance is shown in Figure 2. The dominant taxonomic families identified were Palaemonidae, Viviparidae and Chironomidae, accounted for 51.05\%, $15.26 \%$ and $13.68 \%$ relative abundance respectively. The Palaemon paucidens was the most abundant species accounting for $50.00 \%$ of the total abundance in spring, $39.13 \%$ in summer, $53.85 \%$ in autumn; Followed by Bellamya purificata accounting for $8.00 \%$ of the total abundance in spring, $13.04 \%$ in summer, $18.80 \%$ in autumn. Additionally, it indicated from Figure 2 that the species diversity was higher in autumn than in spring and summer. Site S1 provides the highest relative abundance during the sampling period, and site S7 had the lowest relative abundance, as shown in Figure 3.

\section{Benthic macroinvertebrates functional groups in temporal variation}

It recorded 21 taxa of benthic macroinvertebrates belonging to 4 groups in functional feeding groups, and five groups in locomotion groups (Tables 1 and 4). In investigated period the dominant functional feeding groups functional group was OM mainly comprised by Decapoda $(50.00 \%, 39.13 \%, 57.26 \%$ in spring, summer and winter respectively); Locomotion groups were dominated by $\mathrm{CM}$, which also contributed by 
Decapoda $(50.00 \%, 39.13 \%, 57.26 \%$ in spring, summer and autumn respectively); DI, SP and PR were only appeared in autumn, and had the little relative abundance (Fig. 4). From Figure 5 we found that FC (in locomotion groups) and BU (in functional feeding groups) were dominant groups in S6, S7, S8 and S9.

Table 4. Diversity broad outline, functional groups, and relative abundance of benthic macroinvertebrates during three sampling periods collected in Keqin Lake

\begin{tabular}{|c|c|c|c|c|c|}
\hline Order & Family & Species & $\begin{array}{c}\text { Functional feeding } \\
\text { groups }\end{array}$ & $\begin{array}{c}\text { Locomotion } \\
\text { groups }\end{array}$ & $(\%)$ \\
\hline \multirow{2}{*}{ Decapoda } & Palaemonidae & Palaemon paucidens & $\mathrm{OM}$ & $\mathrm{CM}$ & 51.05 \\
\hline & Atyinae & Neocaridina heteropoda & $\mathrm{OM}$ & $\mathrm{CM}$ & 2.11 \\
\hline \multirow{3}{*}{ Hemiptera } & Belostomatidae & Sphaerodema rusticca & PR & $\mathrm{DI}$ & 1.05 \\
\hline & \multirow{2}{*}{ Corixidae } & Corixinae sp. & PR & DI & 1.58 \\
\hline & & Agraptocorixa sp. & PR & DI & 0.53 \\
\hline \multirow{3}{*}{ Mesogastropoda } & Viviparidae & Bellamya purificata & $\mathrm{SC}$ & $\mathrm{CN}$ & 15.26 \\
\hline & \multirow{2}{*}{ Hydrobiidae } & Parafossarulus striatulus & $\mathrm{SC}$ & $\mathrm{CN}$ & 3.68 \\
\hline & & Bithynia fuchsiana & $\mathrm{SC}$ & $\mathrm{CN}$ & 0.53 \\
\hline \multirow{4}{*}{ Basommatophora } & Valvatidae & Vavata piseinatis & $\mathrm{SC}$ & $\mathrm{CN}$ & 0.53 \\
\hline & Planorbidae & Polypylis hemisphaerula & $\mathrm{SC}$ & $\mathrm{CN}$ & 1.58 \\
\hline & \multirow{2}{*}{ Lymnaeidae } & Radix ovata & $\mathrm{SC}$ & $\mathrm{CN}$ & 2.11 \\
\hline & & R. auricularia & $\mathrm{SC}$ & $\mathrm{CN}$ & 2.11 \\
\hline \multirow{2}{*}{ Eulamellibranchia } & Sphaeriidae & Sphaerium lacustre & $\mathrm{FC}$ & $\mathrm{CN}$ & 1.05 \\
\hline & Unionidae & Cristaria plicata & $\mathrm{FC}$ & $\mathrm{CN}$ & 1.05 \\
\hline Odonata & Platycnemididae & Platycnemididae sp. & PR & SP & 0.53 \\
\hline \multirow{4}{*}{ Diptera } & \multirow{4}{*}{ Chironomidae } & Chironomus sp. & $\mathrm{FC}$ & $\mathrm{BU}$ & 5.77 \\
\hline & & Einfeldia sp. & $\mathrm{FC}$ & $\mathrm{BU}$ & 4.21 \\
\hline & & Glyptotendipes sp. & $\mathrm{FC}$ & $\mathrm{BU}$ & 2.11 \\
\hline & & Polypedilum sp. & $\mathrm{FC}$ & $\mathrm{BU}$ & 1.58 \\
\hline Pharyngobdellida & Erpobdellidae & Erpobdella octoculata & PR & $\mathrm{CN}$ & 1.05 \\
\hline Rhynchobdellida & Glossiphoniidae & Helobdella stagnalis & $\mathrm{PR}$ & $\mathrm{CN}$ & 0.53 \\
\hline
\end{tabular}

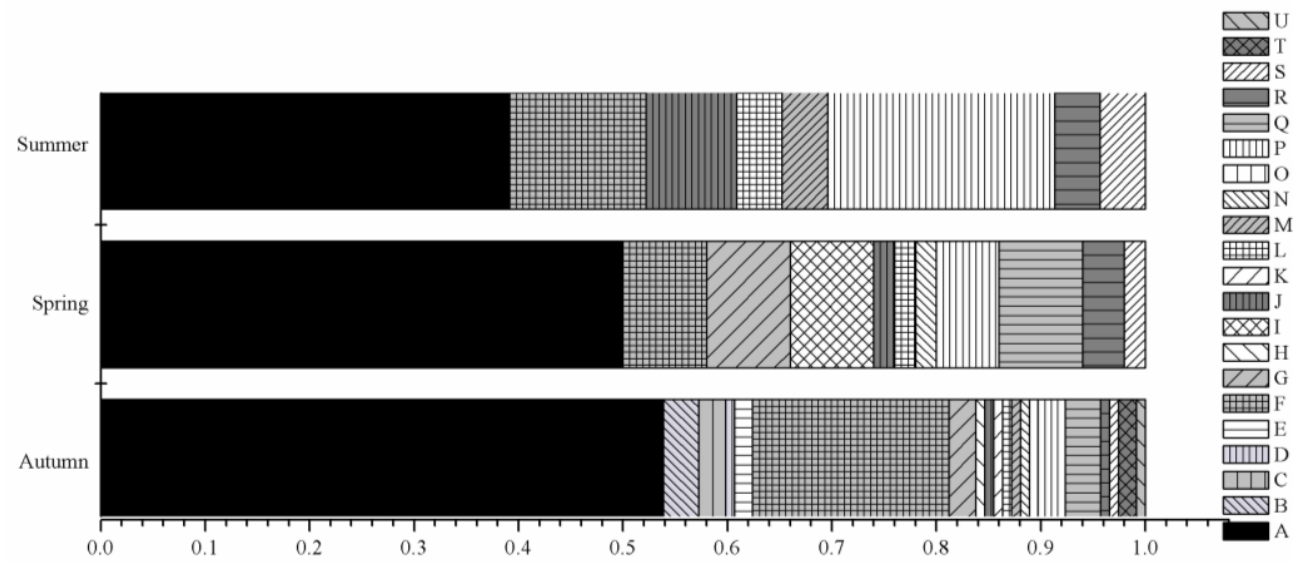

Figure 2. Relative abundance of 21 taxa according to identification. A: Palaemon paucidens, B: Neocaridina heteropoda, C: Corixinae sp., D: Agraptocorixa sp., E: Sphaerodema rusticca, F: Bellamya purificata, G: Parafossarulus striatulus, H: Bithynia fuchsiana, I: Radix ovata, J: R. auricularia, K: Vavata piseinatis, L: Polypylis hemisphaerula, M: Sphaerium lacustre, $N$ : Cristaria plicata, O: platycnemididae sp., P: Chironomus Meigen sp., Q: Einfeldia sp., R: Glyptotendipes sp., S: Polypedilum sp., T: Erpobdella octoculata Linnaeus, U: Helobdella stagnalis 


$$
-286-
$$



Figure 3. Relative abundance of benthic macroinvertebrates per site at each season (the sum of relative abundances of all sites is 100\%)



(a)

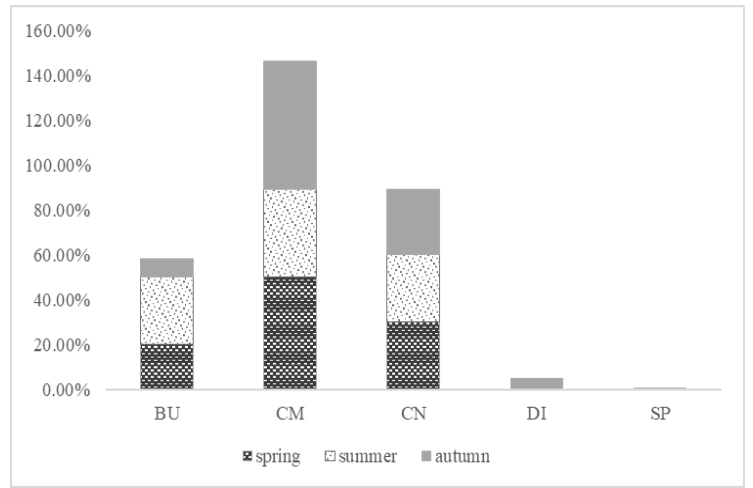

(b)

Figure 4. Relative abundance of benthic macroinvertebrates functional groups in three season. (a) Functional feeding groups; (b) locomotion groups. FC (Filter-feeders), OM (Omnivores), PR (Predators), SC (Scrapers), BU (Burrowers), CM (Climbers), CN (Clingers), DI (Divers), $S P$ (Sprawlers)

\section{Relationships between benthic macroinvertebrates functional groups and physicochemical factors}

The relationships between physicochemical factors and benthic macroinvertebrates functional groups were explained by RDA. The relationships between functional groups and physicochemical factors are described in the RDA ordination diagram (Figs. 6, 7). Different physicochemical indexes were significantly correlated with each functional groups.

The nine groups were categorized as follows: FC (Filter-feeders), OM (Omnivores), PR (Predators), SC (Scrapers), BU (Burrowers), CM (Climbers), CN (Clingers), DI (Divers), SP (Sprawlers). Among the variables included in the RDA, $\mathrm{COD}_{\mathrm{Mn}}, \mathrm{Cl}^{-}, \mathrm{NTU}$ were crucial physicochemical factors which affected the functional feeding groups and locomotion groups significantly. 


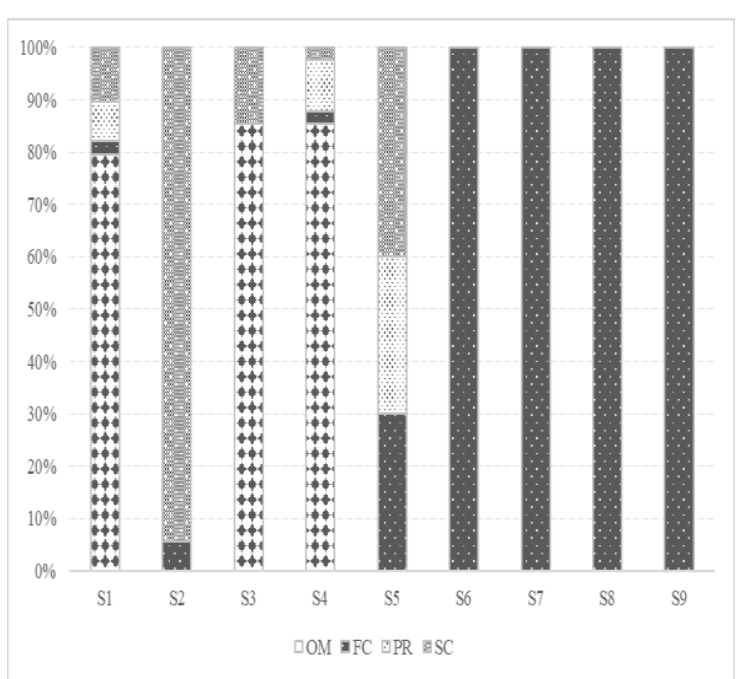

(a)

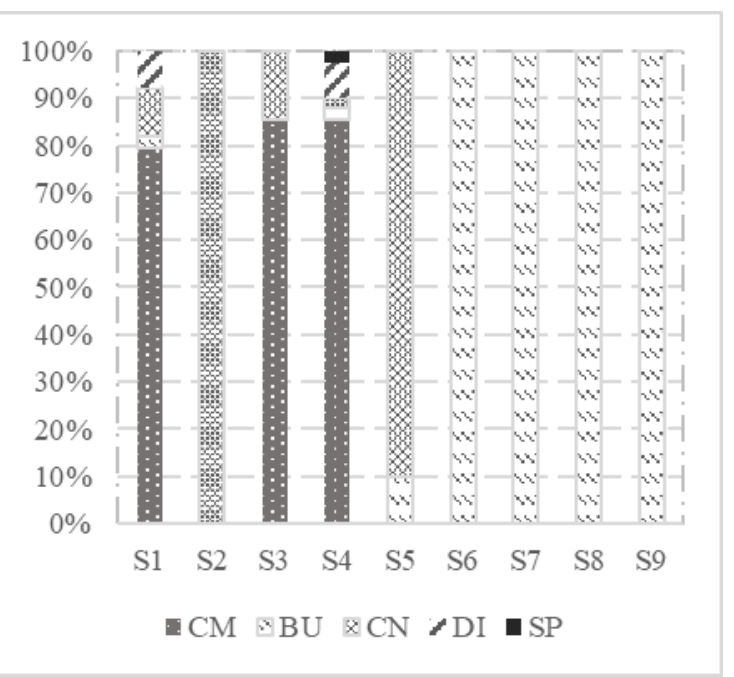

(b)

Figure 5. Relative abundance of benthic macroinvertebrates functional groups among sampling sites: (a) Functional feeding groups, (b) locomotion groups. FC (Filter-feeders), OM (Omnivores), PR (Predators), SC (Scrapers), BU (Burrowers), CM (Climbers), CN (Clingers), DI (Divers), SP (Sprawlers)

The relationships between functional feeding groups and physicochemical factors

The first two RDA axes respectively illustrated 0.796 and 0.609 of macroinvertebrate and environment correlation, with eigenvalues of 0.36 and $0.10 . \mathrm{COD}_{\mathrm{Mn}}$ and $\mathrm{Cl}^{-}$were positively associated with axis 1 , NTU was negatively correlated with axis 1 . OM, PR and $\mathrm{SC}$ were positively correlated with $\mathrm{COD}_{\mathrm{Mn}}$ and $\mathrm{Cl}^{-} ; \mathrm{FC}$ was positively correlated with NTU (Fig. 6).

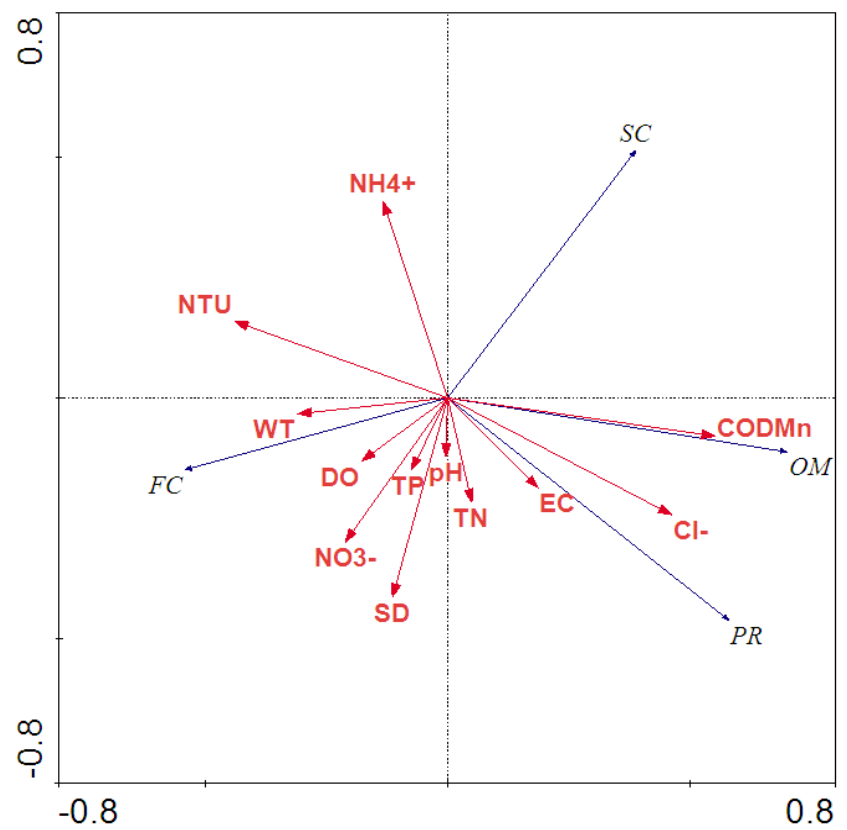

Figure 6. RDA ordination diagram of the functional feeding groups and physicochemical variables FC (Filter-feeders), OM (Omnivores), PR (Predators), SC (Scrapers) 
The relationships between locomotion groups and physicochemical factors

The functional groups and physicochemical correlations for axis 1 and axis 2 were 0.821 and 0.527 , respectively. The eigenvalues were 0.36 in axis 1 and 0.10 in axis 2 . $\mathrm{COD}_{\mathrm{Mn}}$ and $\mathrm{Cl}$ - were positively associated with axis 1, NTU was negatively correlated with axis 1 . CN, CM, DI, SP were positively correlated with $\mathrm{COD}_{\mathrm{Mn}}$ and $\mathrm{Cl}^{-}$; $\mathrm{BU}$ was positively correlated with NTU (Fig. 7).

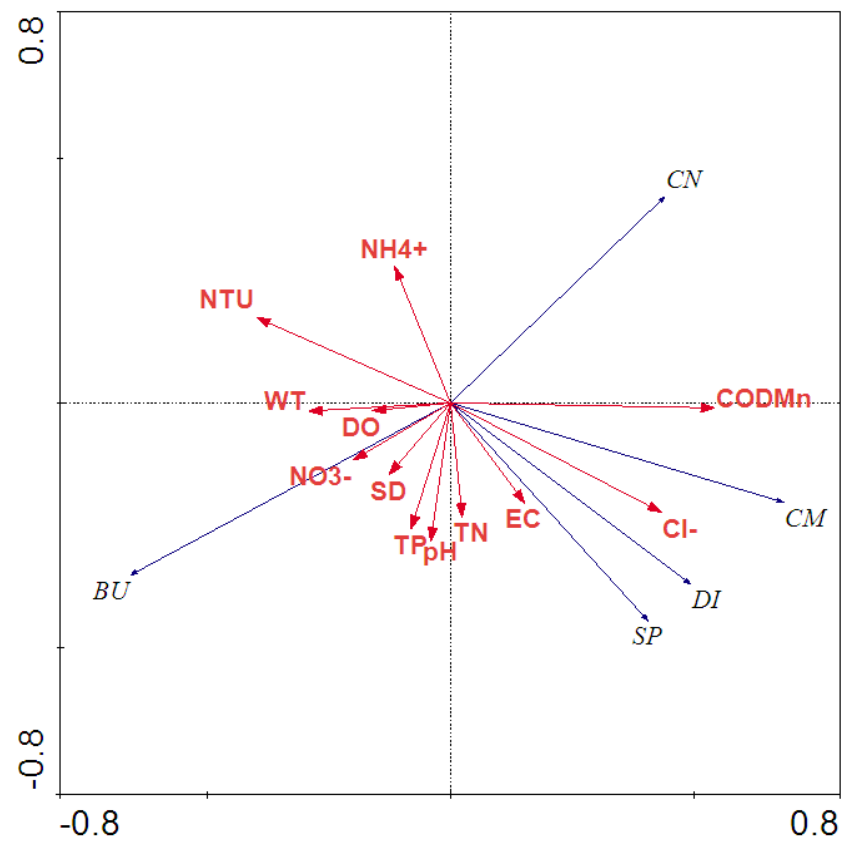

Figure 7. RDA ordination diagram of the locomotion groups and physicochemical variables $B U$ (Burrowers), CM (Climbers), CN (Clingers), DI (Divers), SP (Sprawlers)

\section{Discussion}

\section{Benthic macroinvertebrates functional groups in Keqin Lake}

The functional feeding groups and locomotion groups show consistency in Keqin Lake, OM was dominant in functional feeding groups group, and CM was dominant in locomotion groups. OM and CM mainly composed of Palaemon paucidens $(96.04 \%$ relative abundance in OM, 96.04\% relative abundance in CM). Palaemon paucidens has the wide functional feeding groups, less influenced by seasonal changes, and the population number usually increases in autumn. SC (in functional feeding groups group) and $\mathrm{CN}$ (in locomotion groups) appeared in three seasons, and dominant by molluscs. Some studies demonstrated that molluscs played a crucial role in lake wetland ecosystem and had significant ecological functions (Ngor et al., 2018; Chea et al., 2016). The bottom of the west bank of Keqin Lake was covered by sandy mud, and relatively more molluscs were found here in three seasons, which indicating that the density distribution of molluscs were affected by the bottom material in lake (Zamorano et al., 2007). PR (in functional feeding groups), DI and SP (in locomotion groups) only appeared in autumn. One feasible reason is that the diversity of benthic macroinvertebrates in autumn is higher than other seasons in cold temperate region (Huo et al., 2013; Li, 2012). 
The relative abundance was high in S1, S2 and S3 probably due to the habitat with lush aquatic vascular plant vegetation at edge of the macrophyte bed. The distribution of benthic macroinvertebrates is determined by vegetation types, especially the structure and growth form of the dominant aquatic vascular plants (Kaskela et al., 2017). Actions prioritizing the development of vegetation species-rich will be likely to benefit benthic macroinvertebrates biodiversity (Law et al., 2019). S6, S7, S8 and S9 were dominated by FC (in locomotion groups) and BU (in functional feeding groups), account for the location of sample sites and sediments of lake bottom. These sites locate in the middle of lake with fewer macrophyte but more white mud. Therefore, Chironomidae was dominated in S6, S7, S8 and S9.

\section{Physicochemical factors possessing the benthic macroinvertebrates functional groups}

The benthic macroinvertebrates play a significant role in ecosystem evolution, such as nutrient cycling, pollutant metabolism, and secondary production in lake sediments. The species composition and abundance of benthic macroinvertebrates varied with changes in water temperature (WT), dissolved oxygen (DO), sediment type, water velocity, and mud (or sand) content (Inagaki et al., 2012). The RDA ordination diagram described the relationships between functional groups and physicochemical factors: the different groups were significantly correlated with each physicochemical variables, illustrating that different groups were influenced by different physical and chemical factors, which were related to their ecological characteristics. Group OM was found to be the dominant group at the sampling period (Fig. 3), suggesting that OM was well adjusted to the habitat of Keqin Lake. In the current study, OM was significantly positively correlated with $\mathrm{COD}_{\mathrm{Mn}}$ (Fig. 4). In our research, the groups OM which were contained by Decapoda mainly fed on plankton, containing phytoplankton and zooplankton. Zooplankton also feed on phytoplankton. This means that the group OM was basically commanded by phytoplankton. The growth and productivity of phytoplankton are affected by many factors. One of the most essential factors is the chemical oxygen demand (COD $\mathrm{Mn})$ (Collins and Williner, 2003). Generally, phytoplankton reveals the maximum productivity in high $\mathrm{COD}_{\mathrm{Mn}}$ (Petar et al., 2014; Wang et al., 2007). Consequently, it is no wonder that the groups OM is significantly positively correlated with $\mathrm{COD}_{\mathrm{Mn}}$.

It appears that the occurrence of these species in the Keqin Lake is not driven by a single environmental factor. BU and FC both were positively correlated with NTU, which could be interpreted by the biotope they stayed. FC is composed of Sphaeriidae, Unionidae and Chironomidae; BU is composed of Chironomidae. These three families generally settle in high polluted bottoms. But in the previous study, it has strong negative correlations between macroinvertebrate densities and turbidity (Anderson et al., 2006). According to Rosillon (1989), catastrophic and unpredictable fluctuation of abiotic factors will cause disturbance of stream invertebrate community, but the response to these events varies with species.

As it is indicated in RDA analysis, Chloride $\left(\mathrm{Cl}^{-}\right)$became the significant physicochemical factor, what probably due to industrial effluents from factories, and in some instances effluents form farmland nearby. The increasing chloride levels will lead to the death of benthic macroinvertebrates (Benbow and Merritt, 2004). Nevertheless, the higher chlorides improved stream conditions by flocculation of suspended solids and reducing turbidity (Darville and Harrel, 1980). Therefore, it is necessary to set valid pollution precaution plans to governance eutrophication in Keqin Lake. 


\section{Conclusion}

During the sampling periods in the Keqin Lake, 21 taxa of benthic macroinvertebrates were recorded belonging to four functional feeding groups and five locomotion groups. We found that Palaemon paucidens was the most species in the three seasons, autumn has the most significant number of species and individuals. In accordance with redundancy analysis (RDA), $\mathrm{COD}_{\mathrm{Mn}}, \mathrm{Cl}^{-}$and $\mathrm{NTU}$ were significantly physicochemical factors correlated with functional groups. It was found that $\mathrm{OM}$ (Omnivores), PR (Predators), SC (Scrapers), CN (Clingers), CM (Climbers), DI (Divers), SP (Sprawlers) were positively correlated with $\mathrm{COD}_{\mathrm{Mn}}$ and $\mathrm{Cl}^{-}$; $\mathrm{FC}$ (Filterfeeders) and BU (Burrowers) were positively correlated with NTU.

If functional groups provide a valuable alternative for studying communities and lake ecosystems, this approach is highly dependent on the availability of biological and ecological information. But the lack of data forced us to omit potentially important variables such as, fecundity and dispersal potential. This fact emphasizes the importance to continue the basic researches on benthic macroinvertebrates species life history characteristics and ecological requirements which can improve our understanding of these biological and ecological information.

Acknowledgements. This work was supported by the National Key Research and Development Program of China (2016YFC0500406). We thank Zhalong Nature Reserve Administration for support during fieldwork.

Conflict of interests. None of the authors have any conflict of interests to declare.

\section{REFERENCES}

[1] Alcocer, J., Oseguera, L., Escobar, E., Reznickova, P. (2016): The littoral benthic macroinvertebrate community as a reflection of environmental heterogeneity. Hidrobiologica 26(3): 403-418.

[2] Anderson, B. S., Phillips, B. M., Hunt, J. W., Connor, V., Richard, N., Tjeerdema, R. S. (2006): Identifying primary stressors impacting macroinvertebrates in the Salinas River (California, USA): Relative effects of pesticides and suspended particles. Environmental Pollution 141(3): 402-408.

[3] Benbow, M. E., Merritt, R. W. (2004): Road-salt toxicity of select Michigan wetland macroinvertebrates under different testing conditions. - Wetlands 24(1): 68-76.

[4] Bremner, J., Rogers, S. I., Frid, C. L. J. (2006): Methods for describing ecological functioning of marine benthic assemblages using biological traits analysis (BTA). Ecological Indicators 6(3): 0-622.

[5] Chea, R., Guo, C., Grenouillet, G., Lek, S. (2016): Toward an ecological understanding of a flood-pulse system lake in a tropical ecosystem: food web structure and ecosystem health. - Ecological Modelling 323: 1-11.

[6] Collins, P. A., Williner, V. (2003): Feeding of Acetes paraguayensis (Nobili) (Decapoda: Sergestidae) from the Parana River, Argentina. - Hydrobiologia 493(1-3): 1-6.

[7] Cummins, W. K. (1973): Trophic relations of aquatic insects. - Annual Review of Entomology 18(1): 183-206.

[8] Daily, G. C. (1997): Nature's Services (Vol. 1997/1). - Island Press, Washington, DC.

[9] Darville, R. G., Harrel, R. C. (1980): Macrobenthos of Pine Island Bayou in the Big Thicket National Preserve, Texas. - Hydrobiologia 69(3): 213-223.

[10] Duan, X., Wang, Z., Xu, M. (2010): Benthic Macroinvertebrates and Application in the Assessment of Stream Ecology. - Tsinghua University Press, Beijing (in Chinese). 
[11] Dudgeon, D. (1999): Tropical Asian Streams: Zoobenthos, Ecology and Conservation. Hong Kong University Press, Hong Kong.

[12] Gamito, S., Furtado, R. (2009): Feeding diversity in macroinvertebrate communities: a contribution to estimate the ecological status in shallow waters. - Ecological Indicators 9(5): 1009-1019.

[13] Huo, T., Li, Z., Jiang, Z., Ma, B., Yu, H. (2013): Macrozoobenthos community structure and water quality bioassessment in the mid-reaches of the Heilongjiang River. - Journal of Fishery Sciences of China 20(1): 177-188 (in Chinese).

[14] Inagaki, Y., Takatsu, T., Ashida, Y., Takahashi, T. (2012): Annual changes in macrobenthos abundance in Funka Bay, Japan. - Fisheries Science (Tokyo) 78(3): 647659.

[15] Kaskela, A. M., Rousi, H., Ronkainen, M., Orlova, M., Zhamoida, V. (2017): Linkages between benthic assemblages and physical environmental factors: the role of geodiversity in eastern Gulf of Finland ecosystems. - Continental Shelf Research 142: 1-13.

[16] Law, A., Baker, A., Sayer, C., Foster, G., Gunn, I. D., Taylor, P., Willby, N. J. (2019): The effectiveness of aquatic plants as surrogates for wider biodiversity in standing fresh waters. - Freshwater Biology 64(9): 1664-1675.

[17] Li, J. J. (2012): Study on the ecology of macrobenthos in Xiquanyan Reservoir. - PhD thesis. University of Northeast Forestry, China (in Chinese).

[18] Li, L. J., Chong, X. Y., Sheng, C. H., Yin, X. W., Xu, Z. X., Zhang, Y. (2019): Response of riparian land-use types to functional groups of benthic macroinvertebrates in Taizi River, Liaoning Province. - Acta Ecologica Sinica 39(22): 8667-8674 (in Chinese).

[19] Liu, M. H., Meng, Y., Cui, J. J., Cao, X. B., Al, M. N. (2019a): Functional Traits of Macroinvertebrates in Naolihe Wetland. - Journal of Northeast Forestry University 47(1): 76-82 (in Chinese).

[20] Liu, X., Li, K., Zhou, Y., Xu, Y., Ouyang, S. (2019b): Temporal and spatial changes in macrozoobenthos diversity in Poyang Lake Basin, China. - Ecology and Evolution 9(2).

[21] Merritt, R. W., Cummins, K. W., Berg, M. B. (1996): An Introduction to the Aquatic Insects of North America. Third Ed. - Kendall/Hunt Publishing Company, Dubuque.

[22] Morse, C. J., Yang, L., Tian, L. (1994): Aquatic Insects of China Useful for Monitoring Water Quality. - Hohai University Press, Nanjing, China.

[23] Ngor, P. B., Sor, R., Prak, L. H., So, N., Hogan, Z. S., Lek, S. (2018): Mollusc fisheries and length-weight relationship in Tonle Sap flood pulse system, Cambodia. - Annales de Limnologie - International Journal of Limnology 54: 34.

[24] Petar, Ž., Marija, G. U., Koraljka, K. B., Anđelka, P. M., Judit, P. (2014): Morphofunctional classifications of phytoplankton assemblages of two deep karstic lakes. Hydrobiologia 740(1): 147-166.

[25] Poff, N. L., Olden, J. D., Vieira, N. K., Finn, D. S., Simmons, M. P., Kondratieff, B. C. (2006): Functional trait niches of North American lotic insects: traits-based ecological applications in light of phylogenetic relationships. - Journal of the North American Benthological Society 25(4): 730-755.

[26] Postel, S., Carpenter, S. (1997): Freshwater Ecosystem Services. - In: Daily, G. (ed.) Nature's Services: Societal Dependence on Natural Ecosystems. Island Press, Washington, DC, pp. 195-214.

[27] Rosillon, D. (1989): The influence of abiotic factors and densitydependent mechanisms on between-year variations in a stream invertebrate community. - Hydrobiologia 179: 2538 .

[28] Thorp, J. H., Covich, A. P. (1991): Ecology and Classification of North American Freshwater Invertebrates. - Academic Press, New York.

[29] Usseglio-Polatera, P., Bournaud, M., Richoux, P., Tachet, H. (2000): Biological and ecological traits of benthic freshwater macroinvertebrates: relationships and definition of groups with similar traits. - Freshwater Biology 43(2): 175-205. 
[30] Wang, X. L., Lu, Y. L., He, G. Z., Han, J. Y., Wang, T. Y. (2007): Exploration of relationships between phytoplankton biomass and related environmental variables using multivariate statistic analysis in a eutrophic shallow lake: a 5-year study. - Journal of Environmental Sciences 19(8): 920-927.

[31] Wei, F. S., Qi, W. Q., Sun, Z. G., Huang, Y. R., Shen, Y. W. (2002): Water and Wastewater Monitoring and Analysis Method. - China Environmental Science Press, China, pp. 211-284 (in Chinese).

[32] Zamorano, P., Hendrickx, M. E., Toledano-Granados, A. (2007): Distribution and ecology of deep-water mollusks from the continental slope, southeastern Gulf of California, Mexico. - Marine Biology 150(5): 883-892.

[33] Zhang, N., Xiao, X., Pei, M., Liu, X., Liang, Y. (2016): Discordant temporal turnovers of sediment bacterial and eukaryotic communities in response to dredging: non-resilience and functional changes. - Applied and Environmental Microbiology AEM 02526-16.

[34] Zhu, C. X., Mo, K. L., Tang, L., Wu, Y., Li, T., Lin, Y. Q., Chen, Q. W. (2020): Spatialtemporal distribution and ecological effects of macroinvertebrate functional feeding groups in the Lijiang River. - Acta Ecologica Sinica 40(1): 60-69 (in Chinese). 